\title{
Acoustic structure of male loud-calls support molecular phylogeny of Sumatran and Javanese leaf monkeys (genus Presbytis)
}

Dirk Meyer ${ }^{1,2^{*}}$, John K Hodges $^{1}$, Dones Rinaldi ${ }^{3}$, Ambang Wijaya ${ }^{3,4}$, Christian Roos ${ }^{5}$ and Kurt Hammerschmidt ${ }^{6}$

\begin{abstract}
Background: The degree to which loud-calls in nonhuman primates can be used as a reliable taxonomic tool is the subject of ongoing debate. A recent study on crested gibbons showed that these species can be well distinguished by their songs; even at the population level the authors found reliable differences. Although there are some further studies on geographic and phylogenetic differences in loud-calls of nonhuman primate species, it is unclear to what extent loud-calls of other species have a similar close relation between acoustic structure, phylogenetic relatedness and geographic distance. We therefore conducted a field survey in 19 locations on Sumatra, Java and the Mentawai islands to record male loud-calls of wild surilis (Presbytis), a genus of Asian leaf monkeys (Colobinae) with disputed taxanomy, and compared the structure of their loud-calls with a molecular genetic analysis.

Results: The acoustic analysis of 100 surili male loud-calls from 68 wild animals confirms the differentiation of $P$. potenziani, P.comata, P.thomasi and P.melalophos. In a more detailed acoustic analysis of subspecies of $P$. melalophos, a further separation of the southern P.m.mitrata confirms the proposed paraphyly of this group. In concordance with their geographic distribution we found the highest correlation between call structure and genetic similarity, and lesser significant correlations between call structure and geographic distance, and genetic similarity and geographic distance.

Conclusions: In this study we show, that as in crested gibbons, the acoustic structure of surili loud-calls is a reliable tool to distinguish between species and to verify phylogenetic relatedness and migration backgrounds of respective taxa. Since vocal production in other nonhuman primates show similar constraints, it is likely that an acoustic analysis of call structure can help to clarify taxonomic and phylogenetic relationships.
\end{abstract}

\section{Background}

Langurs of the Asian colobine genus Presbytis (surilis) are exclusively arboreal animals, which inhabit tropical rainforest habitats of Sundaland, i.e., the Malay peninsula and the western Indo-Malay archipelago, comprising of Sumatra, Borneo, Java, the Mentawai islands and some smaller interjacent islands [1]. Mainly driven by Sundaland's dramatic geological and climatic changes during the past million years, the genus has undergone an extensive radiation [2]. With more than 50 described color variants $[3,4]$, Presbytis is one of the most diverse primate genera among Old World monkeys.

\footnotetext{
* Correspondence: dirk.meyer@redape.de

${ }^{1}$ Reproductive Biology Unit, German Primate Center, Göttingen, Germany Full list of author information is available at the end of the article
}

Like many other primate species, surilis emit loud, conspicuous vocalizations termed loud-calls or long-distance calls. In contrast to Presbytis, gibbon loud-calls have a well-adapted acoustic structure [5,6]; with an energy concentration in single frequency bands, a slow modulation of song elements and a transmission range adjusted to the frequency window of rainforest conditions, their songs can be heard over several miles $[7,8]$. Although less well optimized, loud-calls produced by other nonhuman primate species, such as howler monkeys [9] or surilis [10], also exhibit adaptations for longdistance transmission. Loud-calls can have a variety of different functions; they may be used to defend resources, to compete for mates, to mediate intergroup spacing and to promote intragroup cohesion $[9,11,12]$.
C Biomed Central

(C) 2012 Meyer et al; licensee BioMed Central Ltd. This is an Open Access article distributed under the terms of the Creative Commons Attribution License (http://creativecommons.org/licenses/by/2.0), which permits unrestricted use, distribution, and reproduction in any medium, provided the original work is properly cited. 
In those species in which the structure of loud-calls is well adapted to long-distance transmission, they function predominantly to mark and defend territories.

Although there is general agreement that loud-calls may also serve as phylogenetic traits, systematic studies comparing call structure and genetic relatedness are rare. Amongst gibbons, structural differences are routinely used as a taxonomic tool $[13,14]$. In a recent study on crested gibbons carried out in 24 different locations in Vietnam, Laos and Cambodia, Thinh and colleagues [15] combined a molecular genetic analysis with an acoustic analysis and showed that song structure alone can be used to distinguish the different species. Based on call structure, the authors were also able to distinguish single populations and support not only their phylogentic relatedness, but also their proposed geographic origins. Comparable studies in other nonhuman primates are lacking. However, single studies on loud-calls of orangutans [16], Thomas langurs [17], chimpanzees [18], black-and-white colobus monkeys [19] or sportive lemurs [20] revealed geographic or genetic related differences in the structure of loud-calls of these species. Some previous studies proposed that loud-calls of surilis could be a useful tool to characterize phylogenetic relatedness [21-23]. According to these studies, the Sumatran surilis were divided into the species P.melalophos, P.femoralis, P.thomasi [21-23] and P.potenziani [21,23], and Wilson and Wilson [23] proposed a successive invasion of Sumatra, Borneo and the Mentawai islands from the Asian mainland. However, all these studies are only based on phonetic descriptions of loud-calls and did not make a systematic analysis of the acoustic structure or a direct comparison between acoustic structure and genetic relatedness.

Here we combine the results of the most comprehensive molecular genetic study on leaf monkeys of the genus Presbytis currently available [24] with a systematic field survey in which the loud-calls of P.potenziani siberu, P.comata comata, P.thomasi and the four subspecies of P.melalophos (melalophos, mitrata, bicolor and sumatrana) were recorded [3]. Previous classifications and phylogenies of Presbytis were mainly based on behavioral and anatomical features, in particular coat coloration $[1,3,4,22,25-31]$, while genetic studies are extremely limited [24,32-34]. In our recent study [24], mitochondrial DNA was used to propose a revision of Groves' classification [3] suggesting species status for the four subspecies of P.melalophos and also for both subspecies of P.comata and P.potenziani. However, for convenience we use here the classification of Groves [3].

Since surilis intensively responds to stranger call playbacks [35], we used a playback design in order to collect vocalization data under comparable conditions. We hypothesized that, similar to crested gibbons, structural differences in Presbytis loud-calls reflect phylogenetic relationships and can support a revision of the current classification.

\section{Results}

In 2007 and 2008, we conducted field surveys in 19 locations (which resemble 19 populations) on Sumatra, Java and the Mentawai islands, and recorded male loudcalls of seven wild non-habituated Presbytis taxa (Figure 1). Included are P.thomasi, P.potenziani siberu, P.comata comata and all four subspecies of P.melalophos (P.m. melalophos, P.m.mitrata, P.m.bicolor and P.m.sumatrana). In total, we recorded more than 300 loud-calls of 68 male individuals.

In response to the playbacks, males often responded several times, but only one call of this bout was used for the analysis (in total 100 calls). Counter calling males in general decreased the distance to the speaker, while females hid or disappeared. A further common response to playback treatments was alarm calling of group members and in addition juveniles often started to squeal [36]. Loud-calls were mostly accompanied by a jumping display.

\section{General differences in male loud-calls}

P.thomasi, P.potenziani, P.comata and P.melalophos can be clearly identified by general acoustic characteristics in their call structure (Figure 2). In addition, species' calls are readily distinguished by ear, but P.melalophos subspecific differences are undetectable.

P.thomasi $(\mathrm{n}=10)$ and P.potenziani $(\mathrm{n}=9)$ calls start with coughing elements at the beginning and end with howling tonal phrases. These two parts include inhalation and exhalation elements. In P.thomasi, the initial coughing elements rise in crescendo and increase in volume (build-up phase). In P. potenziani $(\mathrm{n}=9)$, the build-up phase is missing and the coughing elements are equally loud and noisy (Figure 2). Both loud-calls also differ in their mean duration with $3.58 \mathrm{~s}$ ( SD = $0.35)$ for P.thomasi and $4.17 \mathrm{~s}(\mathrm{SD}=0.42)$ for P.potenziani. On the average, P.potenziani produces 28 elements $(\mathrm{SD}=2)$ per call with a mean element frequency of 6.42 per second $(\mathrm{SD}=0.56)$, while P.thomasi produces 30 elements $(S D=4)$ with a mean element frequency of 8.5 elements/s $(S D=1)$ (Figure 2). Detailed differences in the acoustic structure can be found in Additional File 1.

The typical P.comata call $(\mathrm{n}=10)$ is characterized by a unique staccato-like sequence of $52(\mathrm{SD}=8)$ alternating exhalation and inhalation elements (mean 18.20, SD $=1.91$ elements $/ \mathrm{s})$. P.comata calls, with a mean call duration of $2.86 \mathrm{~s}$ ( $\mathrm{SD}=0.26$ ), include a short build-up phase and an end-up phase, both with increasing loudness and frequency (Figure 2, Additional File 1). 


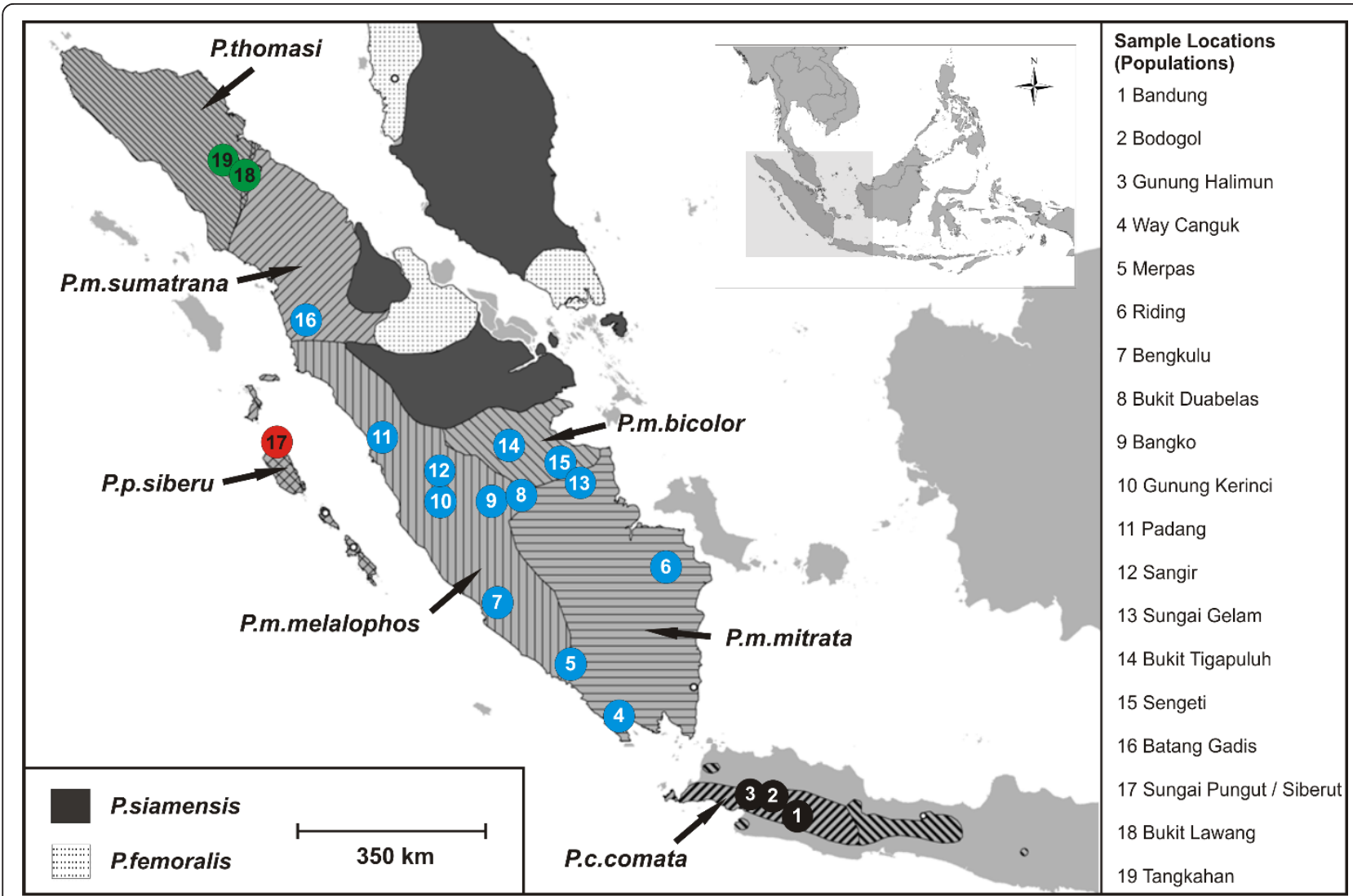

Figure 1 Geographical distribution of Presbytis taxa on Sumatra, Java and the Malay peninsula. Sampled taxa are labeled in the map. Hatched areas in the map indicate distribution ranges of respective taxa, colors indicate species and numbers indicate the origin of acoustic samples (populations).

Loud-calls of P.m.bicolor $(\mathrm{n}=15)$, P.m.sumatrana $(\mathrm{n}$ = 9), the central Sumatran P.m.mitrata $(\mathrm{n}=7)$ and P.m. melalophos $(\mathrm{n}=26)$ from outside of Bengkulu, consist of a sequence of exhalation elements. An exception are the calls of P.m.melalophos from Bengkulu $(\mathrm{n}=3)$ and the southern Sumatran P.m.mitrata $(\mathrm{n}=12)$, which differ by producing alternating exhalation and inhalation elements at the end of the call (Figure 3). The mean duration of P.melalophos calls lies between $2.39 \mathrm{~s}(\mathrm{SD}=$ $0.33)$ for P.m.mitrata and $2.53 \mathrm{~s}(\mathrm{SD}=0.40)$ for P.m. sumatrana. The mean frequency of produced elements lies between 10.85 elements/s, $(\mathrm{SD}=2.36)$ for P.m. mitrata and 7.35 elements/s $(\mathrm{SD}=0.4)$ for P.m.bicolor (Figure 3, Additional File 1).

\section{Subtle differences in male loud-calls}

Result of the discriminant function analysis of all 19 populations (DFA1)

The DFA assigns $72 \%$ of the loud-calls ( $62 \%$ of cross-validated, chance level $=5.3 \%$ ) to the original populations. In relation to taxon identity $83 \%$ of the cross-validated cases are correctly classified. Most misclassified cases are found between P.melalophos subspecies (Table 1).
No misclassification can be found between the four Presbytis species, P.comata (populations 1-3), P.melalophos (populations 4-16), P.potenziani (population 17) and P.thomasi (populations 18-19). They form four well separated clusters with a correct assignment of $100 \%$ (Table 1, Figure 4A). Among the large P.melalophos cluster, one further sub-cluster is indicated, which includes P.m.melalophos from Bengkulu (population 7) and the southern Sumatran P.m.mitrata (populations 46). The scattergram (Figure 4A) shows the separation of the 19 populations according to the first and second discriminant function, explaining $56.3 \%$ and $26.7 \%$ of the total acoustic variation, respectively. The first discriminant function, which mainly represents the amount of inhalation elements, separates populations 1-3 from all others, while the second discriminant function, which represents rhythmical features, separates population 17 from all others. To focus on the P.melalophos cluster (populations 4-16), we conducted a second DFA.

Result of the discriminant function analysis of P.melalophos populations (DFA2)

The second DFA2 assigns $66.2 \%$ of the loud-calls (49.3\% of cross-validated, chance level $=7.7 \%$ ) to the original 


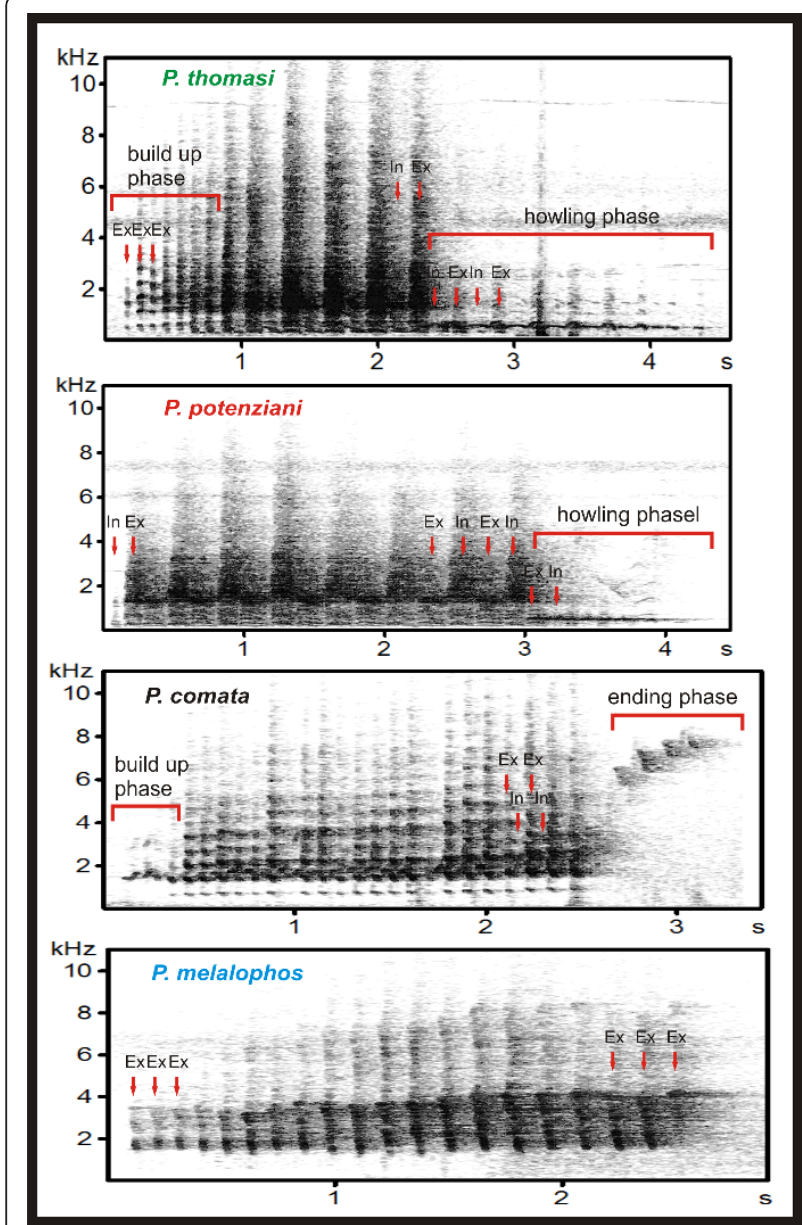

Figure 2 Spectrograms of typical loud-calls of P.thomasi, $P$. potenziani, P.comata and P.melalophos. populations and establishes three distinct clusters (Figure 4B), separating the southern Sumatran P.m.mitrata (populations 4-6) and the P.m.melalophos from Bengkulu (population 7) from the remaining P.melalophos populations.

In relation to the taxon identity $89 \%$ P.m.mitrata, $76 \%$ P.m.melalophos, 93\% P.m.bicolor and 63\% P.m.sumatrana of the cross-validated population cases are correctly classified (Table 1). The scattergram (Figure 4B) shows the separation of the 13 populations according to the first and second discriminant function, explaining $92.9 \%$ and $3.8 \%$ of the total variation, respectively. The first discriminant function, which explains nearly all structural differences, represents the amount of inhalation elements, separates populations 4-6 from population 7 , and the remaining populations. The second discriminant function mainly based on the minimum frequency of the call, indicates the separation of populations 14, 15 and 5 from population 7 and the lasting locations.

\section{Phylogenetic relationships among Presbytis taxa based on} acoustic data and comparison with molecular data

The vocal- (Figure 5A) and molecular-based phylogenies (Figure 5B) [24] are highly congruent. In both phylogenies, P.thomasi, P.potenziani, P.melalophos (excluding P. m.mitrata from South Sumatra) and P.comata + P.m. mitrata from South Sumatra form four distinct clusters/ lineages and indicate a similar branching pattern. Contrary to the molecular phylogeny, in the acoustic tree $P$. m.mitrata from South Sumatra (populations 4-6) does not form a monophyletic cluster, and P.m.sumatrana (population 16) and P.m.bicolor (populations 14-15) are

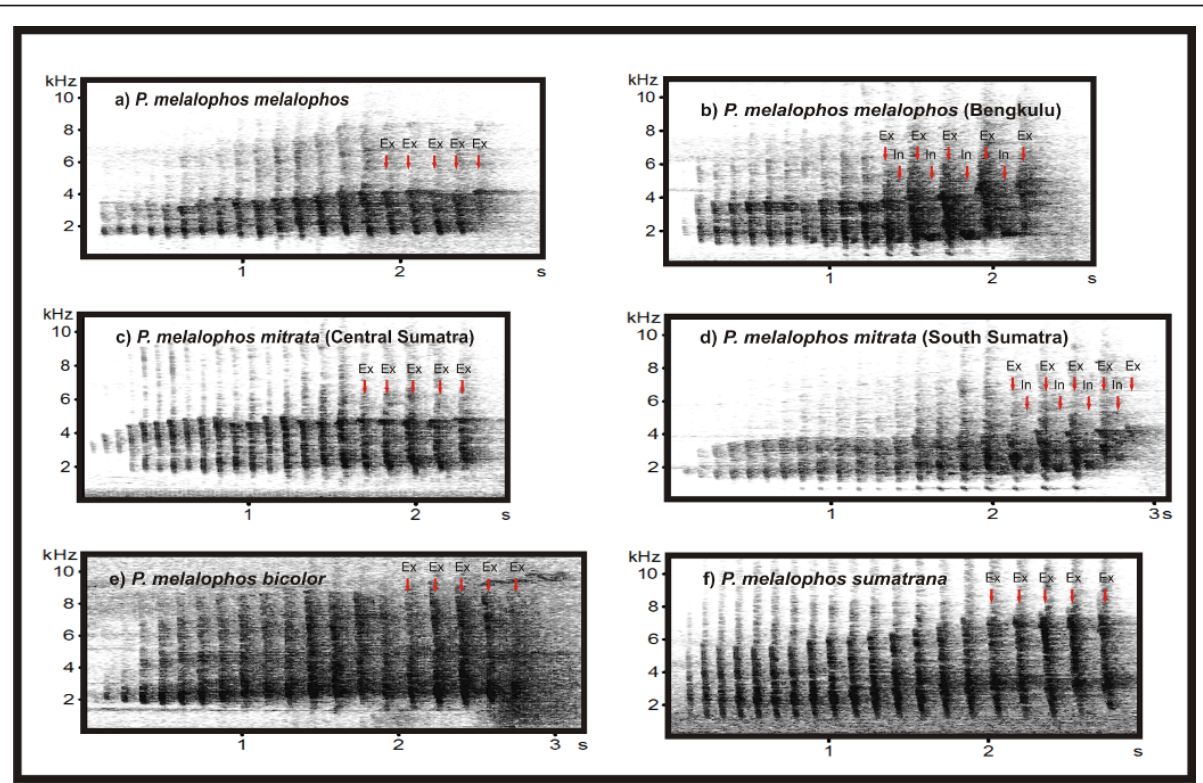

Figure 3 Spectrograms of typical loud-calls of P.melalophos subspecies. 
Table 1 Classification results of the first and second DFA in relation to the taxon membership*

\begin{tabular}{|c|c|c|c|c|c|c|c|}
\hline & $\begin{array}{c}\text { P.comata } \\
\mathrm{n}=10 \\
\text { P } 1-3\end{array}$ & $\begin{array}{c}\text { P.m.mitrata } \\
n=19 \\
\text { P 4-6, } 13\end{array}$ & $\begin{array}{c}\text { P.m.melalophos } \\
n=29 \\
\text { P 7-12 }\end{array}$ & $\begin{array}{c}\text { P.m.bicolor } \\
n=15 \\
\text { P } 14-15\end{array}$ & $\begin{array}{c}\text { P.m.sumatrana } \\
n=8 \\
\text { P } 16\end{array}$ & $\begin{array}{c}\text { P.potenziani } \\
n=9 \\
\text { P } 17\end{array}$ & $\begin{array}{c}\text { P.thomasi } \\
\mathrm{n}=10 \\
\mathrm{P} 18-19\end{array}$ \\
\hline $\begin{array}{l}\text { P.comata } \\
I=8\end{array}$ & 100 & & & & & & \\
\hline $\begin{array}{l}\text { P.m.mitrata } \\
I=13\end{array}$ & & $68 / 89$ & $26 / 11$ & $6 / 0$ & & & \\
\hline P.m.melalophos $\mid=18$ & & $7 / 7$ & $79 / 76$ & $14 / 10$ & $0 / 7$ & & \\
\hline $\begin{array}{l}\text { P.m.bicolor } \\
\mid=13\end{array}$ & & $7 / 0$ & $20 / 7$ & $73 / 93$ & & & \\
\hline P.m.sumatrana $\mid=5$ & & & $12 / 25$ & $0 / 12$ & $88 / 63$ & & \\
\hline $\begin{array}{c}\text { P.potenziani } \\
\quad I=4\end{array}$ & & & & & & 100 & \\
\hline $\begin{array}{l}\text { P.thomasi } \\
\quad \mid=7\end{array}$ & & & & & & & 100 \\
\hline
\end{tabular}

*Relative predicted group membership in \% (DFA 1/DFA 2), $\mathrm{n}=$ calls, $\mathrm{P}=$ population numbers (see also Figure 1 ), $\mathrm{I}=$ individuals.

nested within the cluster consisting of P.m.melaophos and P.m.mitrata from Central Sumatra (populations 713). This might be due to the subtle differences found in the vocal structure of respective populations.

Correlation between vocal structure, genetic and geographical distance

A Mantel test was performed to test the concordance between genetic distance, geographical distance and acoustic similarity. All populations where corresponding genetic data was available $(\mathrm{N}=17)$ were included in the analysis (populations 3 [P.comata], populations 4,6,13 [P.m.mitrata], population 9 [P.m.melalophos], populations 14, 15 [P.m.bicolor], populations 17 [P.potenziani], populations 18, 19 [P.thomasi]; Figure 1). We found the highest significant correlations between vocal structure and genetic distance $\left(P=0.001, R_{x, y}=0.91\right)$, and lower significant correlations between genetic and geographical distance $\left(P=0.001, R_{x, y}=0.66\right)$, and geographical distance and vocal structure $\left(P=0.001, R_{x, y}=0.55\right)$.

\section{Discussion}

Here we report significant differences between loud-call structures of P.thomasi, P.potenziani, P.comata and P. melalophos. Among the latter species a significant separation between the South Sumatran P.m.mitrata and the central Sumatran P.m.mitrata, as well as a further separation between P.m.melalophos from Bengkulu and the remaining P.m.melalophos populations, could be detected. The acoustic discrimination between Presbytis taxa was highly positively correlated with their genetic distance. In addition, we found substantial significant correlations between acoustic similarity and geographic distance and between genetic distance and geographic distance.

In our recent molecular genetic study [24] we suggested a paraphyly for P.m.mitrata, with the central Sumatran populations being closely related to P.m. melalophos and the South Sumatran populations forming a sister lineage to P.comata (Figure 5B). Our current findings on the acoustic structure of loud-calls strongly support these results.

P.m.mitrata was reported to inhabit the area southeast of the Batang Hari river, a large river in central Sumatra. In the west, this subspecies does not extend to the Bukit Barisan range, a mountain range on the western side of Sumatra [26], where P.m.melalophos occurs [3]. Our samples of the central Sumatran P.m.mitrata (population 13) derived from the above described northernmost distribution range of this subspecies, south of the Batang Hari river. Although much paler, the morphological appearance resembles the reddish P.m.melalophos more than the grayish white southern Sumatran P.m.mitrata (Additional File 2). Whether there might be a transition zone between P.m.melalophos and P.m.mitrata demands further research. It is highly likely that P.m.melalophos gradually intergrades with P.m.mitrata, as may be the case between P.m.bicolor and P.m.melalophos [26]. Our results, however, let us conclude that the central Sumatran P.m.mitrata population is the paler color variant of P.m.melalophos. Thus, the geographical distribution range of P.m.melalophos should be extended from the Bukit Barisan range eastwards towards Jambi. The southern Sumatran P.m.mitrata is genetically, morphologically and acoustically distinct from the remaining $P$. melalophos subspecies (see also Additional File 2). Therefore, if the Phylogenetic Species Concept [37,38] is applied, P.m.mitrata would be elevated to a monotypic species P.mitrata Eschscholtz, 1821 [39].

Among P.m.melalophos we found the calls from Bengkulu (population 7) forming a distinct cluster. Unfortunately, genetic data from Bengkulu are lacking, but acoustically, the call types were more closely related to the Southern P.m.mitrata mainly due to the presence of inhalation elements. Historically different color morphs 


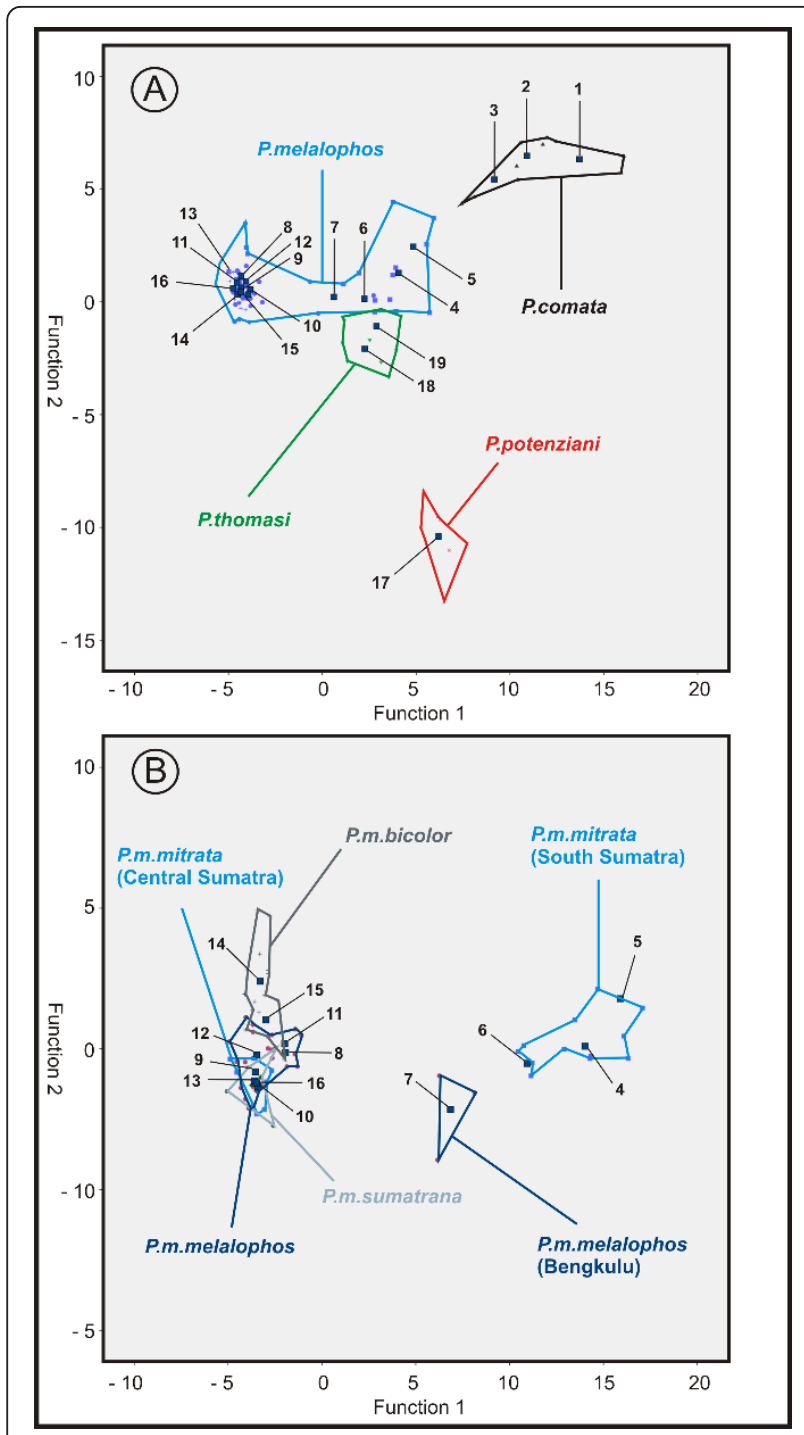

Figure 4 Scattergram presenting the results of the DFA. A: Assignment of the four species P.melalophos, P.comata, P. thomasi and P.potenziani. B: Assignment of P.melalophos subspecies. Rectangles indicate population centroids. Species are marked by color.

of P.m.melalophos were described, all of which are currently classified as synonyms of P.m.melalophos [3]. These are a) the much less red and buffer variant from Bengkulu (Simia melalophos Raffles, 1821; syn. flavimanus Geoffroy, 1830), b) a foxy red northern form (Presbytis nobilis Gray, 1842) from Solok [4], c) a less reddish form from Padang (Semnopithecus ferruginneus Schlegel, 1876) and d) a golden buff variant (Semnopithecus sumatranus var. aurata Müller \& Schlegel, 1841) from Gunung Talamau (ca. $150 \mathrm{~km}$ northwards from Padang) [3]. The great diversity of color morphs in Presbytis, in particular in P.melalophos, has caused much debate over the past decades. Coloration might indicate relatedness, but can often be misleading, in particular, when no broad geographic sampling is available. Our data point out that the taxonomic ranking of some of these historically described taxa possibly should be reconsidered. However, the loud-calls from population 7 are only derived from two individuals and genetic data are missing. Therefore, further molecular genetic and bio-acoustic research based on a broader sampling is needed to draw final conclusions. Of great interest are the acoustic data of the Bornean taxa, in particular data of P.rubicunda. Based on molecular genetic results $P$. melalophos is even polyphyletic since P.rubicunda is nested within the P.m.sumatrana, P.m.bicolor, P.m.melalophos/central Sumatran P.m.mitrata clade [24]. Previous studies already proposed a close affiliation of $P$. rubicunda and P.melalophos based on the red coat coloration [31] or in some aspects of behavior and vocalization [23]. If species status of P.rubicunda is retained, species status of P.m.sumatrana, P.m.bicolor, P.m.melalophos will be consequently warranted, otherwise P.rubicunda has to be assigned as a subspecies of $P$. melalophos.

The correlation between acoustic structure and genetic differences was higher than the correlation between acoustic structure and geographic distance. This pattern can be explained by the following proposed Presbytis migration pattern, which is largely in agreement with Wilson and Wilson [23]. The initial split in Presbytis occurred between P.thomasi and all other taxa, and P.thomasi colonized North Sumatra, which became isolated afterwards. The ancestor of the remaining taxa colonized first Borneo and later Sumatra. An early divergence of Bornean taxa is also supported by previous genetic studies [24,32-34]. Of the ancestral Sumatran stock, one lineage invaded the Mentawai islands $(P$. potenziani), the other split into the proto-P.melalophos lineage and into the southern P.m.mitrata/P.comata lineage (Figure 5). Although calls from P.femoralis/P.siamensis (eastern Sumatra, Asian mainland) are not analysed in our study, previous publications show similarities in call structures of P.femoralis and P.thomasi $[40,41]$. Our genetic study [24] shows that P.femoralis diverged relatively early from other lineages and, thus, the similar call structure of P.femoralis and P.thomasi might be a plesiomorphic feature. Up to this point the genetic, geographic and acoustic differences between populations increased. From this point onwards the geographic distances between populations decreased, because proto-P.melalophos subsequently transmuted into various present day subspecies, which were finally distributed across Sumatra as far as to the distribution range of P.thomasi in North Sumatra. Consequently, the geographic distance between P.thomasi and the remaining Sumatran populations decreased, while the genetic 


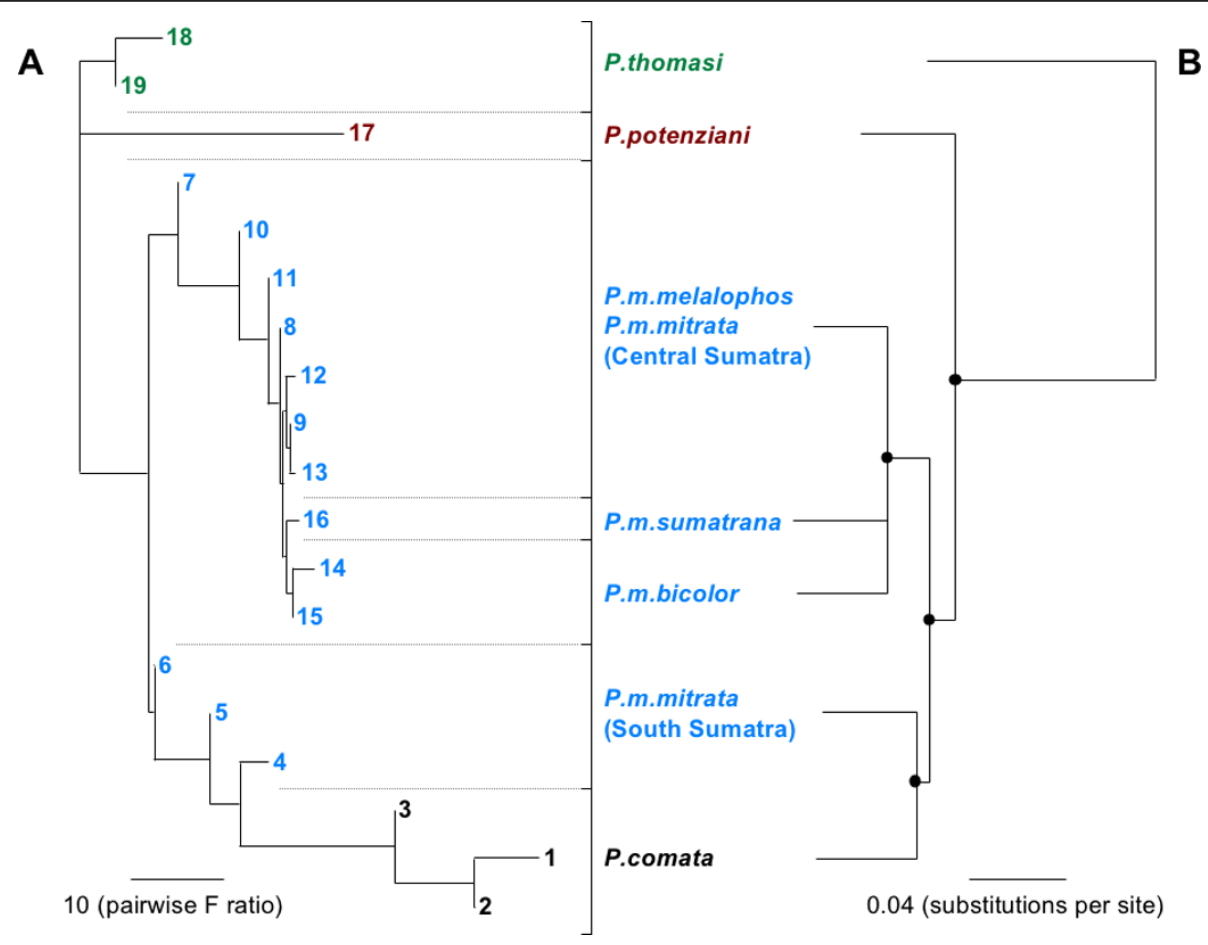

Figure 5 (A) Neighbor-joining tree of Presbytis taxa based on the acoustic similarity matrix (F values) and (B) their phylogenetic relationships according to mitochondrial sequence data (redrawn from [24]). In A, colored letters indicate species and numbers corresponding to sampling locations (see Figure 1). In B, branch lengths refer to those obtained from the Bayesian reconstruction in [24] and black dots on nodes indicate Bayesian posterior probabilities of $>0.96$.

and the acoustic differences increased. Finally, the southern P.m.mitrata/P.comata lineage split into P.m. mitrata and P.comata that colonized Java. In this case we have a linear migration pattern and thus would expect a similar high correlation between acoustic structure, genetic and geographic distance, as it was currently shown in crested gibbons which are proposed to migrate in a linear fashion from North to South [15].

Surilis and gibbons are limited to rainforest habitats where the selection pressure forces an optimal adaptation of the structure of loud-calls for transmission over longer distances [5,42]. Since the structure of loud-calls is inherited and call adaptation forces a similar structure, gene flow could achieve the major influence on the structural variation of calls [15]. By combining the phylogenetic reconstruction of Meyer and colleagues [24] and the results of our study (Figures 2,5A), we can observe a trend to simplification in call structure over time. However, it is difficult to explain why we found such a simplification in call structure. We cannot answer whether this is a general rule or whether this is a Presbytis-specific trait. Crested gibbons show an ambiguous result [15], where after a long period of syllable types with simple frequency modulation, a trend to a slightly more complex modulation appears. More acoustic comparisons with more species and at a higher taxonomic level are necessary to answer this question.

Interestingly, P.potenziani was regarded as most basal lineage [43] and due to similarities in call structure, the species was proposed as closely affiliated with P.thomasi [21]. However, neither is the case, since P.potenziani derived much later [24]. The specific call structure of $P$. potenziani is therefore either the result of an analogous evolution or a pleisiomorphic Presbytis feature. To clarify this issue further research is needed and particularly genetic and acoustic data on the Bornean and Malaysian taxa will help to better understand the evolution and phylogeography of the genus.

For instance, the call structure of P.rubicunda seems to be similar to P.melalophos calls [23] and, as discussed above, molecular genetic data also group P.rubicunda with P.melalophos [24]. This close relationship can partly help to explain the interesting feature of general allopatry of respective Presbytis taxa in Sumatra, and sympatry in Borneo [1]. P.rubicunda originated on Sumatra and subsequently invaded Borneo during the middle Pleistocene via a proposed connection between both islands [44]. At this time Borneo was already colonized by the Bornean species P.chrysomelas, P.frontata and P.hosei. As a result of this second colonization, $P$. 
rubicunda is sympatric today with the three other species wherever their ranges overlap [45].

\section{Conclusions}

In this study we have shown that vocal similarity highly correlates with genetic relatedness; these two measures also correlate significantly with geographic distance, but the strength of the relationship is lower. Accordingly, acoustic analysis of surili loud-calls has been proven to be a promising and powerful tool to support taxonaffiliation and phylogenetic relatedness. In addition, we were able to confirm the proposed paraphyly of P.melalophos by differences in loud-call structure. Furthermore, acoustic analysis can be used as a tool to support proposed migration routes. These findings might also help to explain taxonomic relationships and migration backgrounds in other nonhuman primate taxa, as long as they have similar constraints in their vocal communication.

\section{Methods}

\section{Survey locations and data collection}

In 2007 and 2008 we conducted field surveys in 19 locations on Sumatra, Java and the Mentawai islands, and recorded male loud-calls of P.thomasi, P.potenziani, P. melalophos and P.comata (Figure 2). To find and track animals the field sites were explored between 5.30 am and 6 am until noon, and in the evening from $3 \mathrm{pm}$ till sundown. When a group was encountered GPS data of the location (using a handheld GARMIn ${ }^{\circ}$ GPSMAP 76CSX), information about the group composition and the appearance of the animals (i.e. morphological characters, for instance pelage coloration or scars) were noted on data sheets whenever possible. All visual observations were made by using binoculars $(8 \times 32$ Steiner Sky-Hawk).

Since surilis intensively respond to stranger call playbacks [35], we used a playback design to collect data under comparable conditions. Initially, vocalizations were opportunistically recorded to achieve a high quality call of each population. For the playback the quality of the recorded vocalizations was screened on a notebook using AVISOFT SASLAB Pro software version 5.1 ( $R$. Specht, Berlin, Germany). Undisturbed calls from each population were selected and only one of these was used to stimulate response from respective study populations in the same area. At each site, we tried to avoid recording the same individuals by direct observations. Each playback comprised of 4 calls, which were played back one by one in 20 second intervals.

For the final data collection, playback treatments were amplified with a Vision David Speaker connected to a MP3-Player (Samsung YP-U3) from about $75 \mathrm{~m}$ distance of the focal group at a height of $2 \mathrm{~m}[35,46]$. After the performance at least 15 minutes were recorded. If a response was given before the playback was finished the playback was stopped. To record vocalizations a solid state recorder (Mirant PMD 660 (Marantz, Japan); sampling rate: $44.1 \mathrm{kHz}, 16$ bit amplitude resolution) and a Sennheiser directional microphone (K6 power module, ME66 recording head, MZW66 pro windscreen, Sennheiser, Wedemark, Germany) were utilized. For each playback treatment the GPS position of the location, the group number, the date, time and the identity of a responding male were noted on data sheets.

\section{Acoustic analysis}

Male surili loud-calls consist of iterations of single elements. P.thomasi and P.potenziani produce coughing elements at the beginning of the call. In P.thomasi, the successive elements rise in crescendo and increase in volume (see build up phase Figure 2), while the coughing elements in P.potenziani are equally loud and noisy. Both loud-calls end with howling tonal phrases including inhalation and exhalation elements (Figure 2). We considered these calls as completely developed when both parts were produced. P.comata loud-calls were considered as completely developed when a boost in loudness and frequency till the end of the call was present. P.melalophos loud-calls were considered as completely developed when they included at least 10 elements (the only two calls that were interrupted had less than 10 elements).

AVISOFT SASLAB Pro 5.1 was used to measure acoustic parameters and to generate spectrograms (FFT $=1024$ pt, Frequency resolution = app. $27 \mathrm{~Hz}$ ). To find the point with maximum energy at the beginning, ending and intermediate points of call elements in the spectrogram, the bounded reticule cursor tool of AVISOFT was used. To address different phases within loud-calls, each call was additionally divided into four quarters. Since all taxa produce exhalation elements, the amount of exhalation elements (Ex) was therefore divided by 4 and subsequently multiplied by $1,2,3$ and 4 , respectively. Odd numbers were rounded. If inhalation elements (In) were present; the second, third and fourth quarter always started with an exhalation element (for a detailed description of used parameters see Table 2 and Additional File 3).

\section{Discriminant Function Analysis}

For both Discriminant Function Analyses (DFAs), we excluded acoustic variables that could not be obtained in the majority of loud-calls. In the first DFA we used 23 acoustic parameters for 100 loud-calls from all 19 populations (Table 2, Figure 1). For the second DFA, including only the four P.melalophos subspecies (melalophos, mitrata, sumatrana, bicolor), we used the same 23 


\section{Table 2 Description of acoustic parameters used in the analysis}

\begin{tabular}{|c|c|}
\hline $\begin{array}{l}\text { Parameter } \\
\text { Number }\end{array}$ & Parameter description \\
\hline 1 & Duration of the entire call [s]: from the starting point of the first element till the ending point of the last element \\
\hline 2 & Elements: amount of elements (inhalation and exhalation) \\
\hline 3 & Elements per second $[\mathrm{e} / \mathrm{s}]$ : amount of elements over the duration \\
\hline 4 & Maximum frequency start $[\mathrm{Hz}]$ : maximum frequency of the starting points of the entire elements \\
\hline 5 & Minimum frequency start [Hz]: maximum frequency of the entire starting points of elements \\
\hline 6 & Maximum frequency end $[\mathrm{Hz}]$ : maximum frequency of the entire ending points of elements \\
\hline 7 & Minimum frequency end $[\mathrm{Hz}]$ : minimum frequency of the entire ending points of elements \\
\hline 8 & Mean frequency start $[\mathrm{Hz}]$ : arithmetic mean of the frequency of the entire starting points of elements \\
\hline 9 & Mean frequency end $[\mathrm{Hz}]$ : arithmetic mean of the frequency of the entire ending points of elements \\
\hline 10 & Exhalation elements: amount of exhalation elements \\
\hline 11 & Inhalation elements: amount of inhalation elements \\
\hline $12-15$ & $1^{\text {st }}-, 2^{\text {nd }}-, 3^{\text {rd }}-$ and $4^{\text {th }}$ - quarter elements per second [e/s]: amount of elements over the duration of respective quarters \\
\hline 16 & Middle part elements per second [e/s]: amount of elements over the duration of the $2^{\text {nd }}$ and $3^{\text {rd }}$ quarter \\
\hline $17-20$ & $\begin{array}{l}1^{\text {st }}-, 2^{\text {nd }}-, 3^{\text {rd }}-\text { and } 4^{\text {th }} \text { - quarter mean frequency start [Hz]: arithmetic mean of the frequency of the entire starting points of elements } \\
\text { of respective quarters }\end{array}$ \\
\hline 21 & $\begin{array}{l}\text { Middle part mean frequency start [e/s]: arithmetic mean of the frequency of the entire starting points of elements of the } 2^{\text {nd }} \text { and } 3^{\text {rd }} \\
\text { quarter }\end{array}$ \\
\hline $22-23$ & $\begin{array}{l}1^{\text {st }} \text {-, and } 2^{\text {nd }} \text { - quarter mean frequency end [Hz]: arithmetic mean of the frequency of the entire ending points of elements of } \\
\text { respective quarters }\end{array}$ \\
\hline
\end{tabular}

acoustic parameters for 71 loud-calls (population numbers 4-16, Figure 1). All acoustic parameters were conducted to stepwise DFAs in SPSS 19 [47]. The selection criterion for an acoustic parameter to be entered was $\mathrm{p}$ $=0.05$ and $\mathrm{p}=0.1$ to be removed from the analysis. The assignment of loud-calls to the different populations was cross-validated by the leaving-one-out method [48], which involves leaving out each of the cases in turn, calculating the functions based on the remaining $\mathrm{n}-1$ cases and then classifying the left-out case.

\section{Phylogenetic tree reconstruction}

For reconstructing phylogenetic relationships of loudcall structure, we used the $\mathrm{F}$ values of pairwise distances of the stepwise DFA described above. These F values describe the pairwise similarity of the 19 populations in relation to their overall similarity. Based on these $F$ values, a neighbor-joining tree of acoustic data was reconstructed in the program Neighbor of the PHYLIP package 3.69 [49]. The molecular-based phylogenetic tree derived from mitochondrial sequence data was redrawn from Figure 2 in [24] and shows only taxa included in the present study. Respective branch lengths refer to those obtained from the Bayesian reconstruction in [24].

\section{Correlation analysis between vocal structure, genetic and geographical distance}

To test the statistical relationship between acoustic structure, and genetic and geographic distance matrices, we used a Mantel Test algorithm programmed in $R$ ( $R$.
Mundry, Leipzig, Germany). For the analysis we only used populations where acoustic and genetic data was available $(\mathrm{N}=17)$. The acoustic similarity matrices were generated as described above. Geographic coordinates were obtained via GPS and the geographic distance matrices were calculated from the minimum distance of different groups as implemented in GenAlEx 6.4.1 [50]. GenAlEx was also applied to calculate uncorrected pairwise genetic distances between haplotypes of a $1.8 \mathrm{~kb}$ fragment of the mitochondrial genome. Respective haplotypes were recently published by our group [24] (GenBank accession numbers: JF295100-JF295101 [P.m. mitrata], JF295104 [P.m.melalophos], JF295106-JF295109 [P.m.bicolor], JF295117-JF295118 [P.comata], JF295124JF295125 [P.thomasi], JF295119-JF295121 [P. potenziani]).

\section{Additional material}

Additional file 1: Calculated values of the arithmetic mean and the standard derivation of measured variables (pdf)

Additional file 2: Photographs of wild Presbytis taxa from Sumatra, Java and the Mentawai islands. Numbers refer to locations in Figure 1 (photograph of P.thomasi by Cedric Buttoz Girard, all others by Dirk Meyer \& Ambang Wijaya) (tif).

Additional file 3: Spectrogram of a Presbytis loud-call with examples for measured parameters (tif).

\section{Acknowledgements}

Without the help of numerous people and institutions providing permits, samples and giving logistical, physical, and even psychological support, the present study would not have been possible. We thank the Indonesian 
Institute of Science (LIPI), the Indonesian State Ministry of Research and Technology (RISTEK) and the Indonesian Ministry of Forestry's Department for the Protection Conservation of Nature (PHKA) for granting us research permission and authorizing the study. We also thank the Gunung Halimun Salak National Park (NP), the Gunung Gede Pangrango NP, the Way Kambas NP, the Bukit Barisan Selatan NP, the Siberut NP, the Kerinci Seblat NP, the Balai Konservasi Sumber Daya Alam (BKSDA) Sumbar, the BKSDA Jambi, the BKSDA Sumsel, the BKSDA Sumut, the BKSDA Bengkulu and the BKSDA Jabar for supporting and authorizing field data collection in this study. We are grateful to Rinekso Soekmadi and Muhammad Agil from the Bogor Agricultural University (IPB) for their excellent administrative and logistic support. We thank Peter Pratje from the Sumatran Orangutan Conservation Programme (SOCP), Susan Lappan and Sanha Kim (Gibbon research station Gunung Halimun), Pak Opo (Way Canguk), Christophe Abegg from the Siberut Conservation Project (SCP) and Pak Pri (Way Kanan) for the kind opportunity to use their facilities, logistic support and many fruitful discussions. We also thank Danielle Whittaker, Lisa Paciulli, Pak Yanuar and Pak Kunkun Jaka Gurmaya for obtaining important information on promising field sites and contacts and Julia Fischer, Dietmar Zinner and Peter Kappeler for their support. This study was financially supported by the German Primate Center and the Biodiversitäts-Pakt of the Wissenschaftsgemeinschaft Gottfried-Wilhelm Leibniz. This publication is dedicated to the field assistants Yudi, Aris, Nui, Sahri, Dwi, Insan, Pak Albinus and various rangers for their excellent work during the long and exhausting field surveys.

\section{Author details}

${ }^{1}$ Reproductive Biology Unit, German Primate Center, Göttingen, Germany. ${ }^{2}$ Göttingen Center for Biodiversity and Ecology, Göttingen, Germany. ${ }^{3}$ Department of Forest Resources Conservation and Ecotourism, Bogor Agricultural University, Bogor, Indonesia. ${ }^{4}$ WWF Kalimantan Tengah, Palangkaraya, Indonesia. ${ }^{5}$ Gene Bank of Primates and Primate Genetics Laboratory, German Primate Center, Göttingen, Germany. ${ }^{6}$ Cognitive Ethology Laboratory, German Primate Center, Göttingen, Germany.

\section{Authors' contributions}

DM designed the study, collected acoustic and genetic samples, did laboratory work, analyzed data and wrote the paper. JKH designed the study and wrote the paper. DR collected acoustic data and supported fieldwork. AW collected acoustic and genetic samples and did laboratory work. CR designed the study, did laboratory work, analyzed data and wrote the paper $\mathrm{KH}$ designed the study, analyzed data and wrote the paper. All authors read and approved the final manuscript.

\section{Received: 4 September 2011 Accepted: 6 February 2012}

Published: 6 February 2012

\section{References}

1. Oates JF, Davies AG, Delson E: The diversity of living colobines. In Colobine Monkeys - their Ecology, Behaviour and Evolution. Edited by: Davies AG, Oates JF. Cambridge: Cambridge University Press; 1994:45-73.

2. Meijaard E, Groves CP: The biogeographical evolution and phylogeny of the genus Presbytis. Primate Report 2004, 68:71-90.

3. Groves CP: Primate Taxonomy Washington DC: Smithsonian Institution Press; 2001.

4. Brandon-Jones D, Eudey AA, Geissmann T, Groves CP, Melnick DJ, Morales JC, Shekelle M, Stewart CB: Asian primate classification. Int J Primatol 2004, 25:97-164

5. Schneider C, Hodges JK, Fischer J, Hammerschmidt K: Acoustic niches of Siberut primates. Int J Primatol 2008, 29:601-613.

6. Ryan MJ, Kime NM: Selection on long-distance acoustic signals. In Acoustic Communication. Edited by: Simmons A, Fay R, Popper A. Berlin: Springer; 2003:225-274

7. Padgham M: Reverberation and frequency attenuation in forests implications for acoustic communication in animals. J Acoust Soc Am 2004, 115:402-410

8. Waser PM, Waser MS: Experimental studies of primate vocalization: specializations for long distance propagation. Z Tierpsychol 1977, 43:239-263.

9. Da Cunha RGT, Byrne RW: Roars of black howler monkeys (Alouatta caraya): evidence for a function in inter-group spacing. Behaviour 2006, 143:1169-1199.
10. Wich SA, Koski S, de Vries H, van Schaik CP: Individual and contextual variation in Thomas langur male loud calls. Ethology 2003, 109:1-13.

11. Wich SA, Nunn CL: Do male" long-distance calls" function in mate defense? A comparative study of long-distance calls in primates. Behav Ecol Sociobiol 2002, 52:474-484.

12. Waser PM: Experimental playbacks show vocal mediation of intergroup avoidance in a forest monkey. Nature 1975, 255:56-58.

13. Geissmann T: Taxonomy and evolution of gibbons. In Anthropology and Primatology into the Third Millennium. Edited by: Soligo C, Anzenberger G, Martin RD. New York: Wiley-Liss; 2002:28-31.

14. Geissmann T, Nijman V: Calling in wild silvery gibbons (Hylobates moloch) in Java (Indonesia): behavior, phylogeny, and conservation. Am J Primatol 2006, 68:1-19.

15. Thinh VN, Hallam C, Roos C, Hammerschmidt K: Concordance between vocal and genetic diversity in crested gibbons. BMC Evol Biol 2011, 11:36.

16. Ross MD, Geissmann T: Call diversity of wild male orangutans: a phylogenetic approach. Am J Primatol 2007, 69:305-324.

17. Wich SA, Schel AM, De Vries H: Geographic variation in Thomas langur (Presbytis thomasi) loud calls. Am J Primatol 2008, 70:1-9.

18. Mitani JC, Hunley KL, Murdoch ME: Geographic variation in the calls of wild chimpanzees: a reassessment. Am J Primatol 1999, 47:133-151.

19. Oates JF, Trocco TF: Taxonomy and phylogeny of black-and-white colobus monkeys: inferences from an analysis of loud call variation. Folia Primatol 1983, 40:83-113

20. Méndez-Cárdenas M, Randrianambinina B, Rabesandratana A Rasoloharijaona S, Zimmermann E: Geographic variation in loud calls of sportive lemurs (Lepilemur ssp.) and their implications for conservation. Am J Primatol 2008, 70:828-838.

21. Wilson CC, Wilson WL: Behavioral and morphological variation among primate populations in Sumatra. Ybk Phys Anthropol 1976, 20:207-233.

22. Aimi M, Bakar A: Taxonomy and distribution of Presbytis melalophos group in Sumatera, Indonesia. Primates 1992, 33:191-206.

23. Wilson WL, Wilson CC: Species-specific vocalizations and the determination of phylogenetic affinities of the Presbytis aygulamelalophos group in Sumatra. In Contemporary Primatology. Edited by: Kondo S, Kawai M, Ehara A. Basel: Karger; 1975:459-463.

24. Meyer D, Rinaldi ID, Ramlee H, Perwitasari-Farajallah D, Hodges JK, Roos C Mitochondrial phylogeny of leaf monkeys (genus Presbytis, Eschscholtz, 1821) with implications for taxonomy and conservation. Mol Phylogenet Evol 2011, 59:311-319.

25. Napier JR, Napier PH: A Handbook of Living Primates: Morphology, Ecology and Behaviour of Nonhuman Primates London: Academic Press; 1967.

26. Aimi M, Bakar A: Distribution and deployment of Presbytis melalophos group in Sumatera, Indonesia. Primates 1996, 37:399-409.

27. Hooijer DA: Quaternary langurs and macaques from the Malay Archipelago. Zool Verhandelingen 1962, 55:1-64.

28. Brandon-Jones D: A taxonomic revision of the langurs and leaf monkeys (Primates: Colobinae) of South Asia. Zoos' Print J 2004, 19:1552-1594.

29. Chasen FN: A handlist of Malaysian mammals (a systematic list of the mammals of the Malay Peninsula, Sumatra, Borneo and Java, including the adjacent small islands). Bull Raffles Mus 1940, 15:1-209.

30. Groves CP: A Theory of Human and Primate Evolution Oxford: Clarendon Press; 1989.

31. Brandon-Jones D: Presbytis species sympatry in Borneo versus allopatry in Sumatra: An interpretation. In Tropical Rainforest Research - Current Issues. Edited by: Edwards DS, Booth WE, Choy SC. Dordrecht: Kluwer Academic Publishers; 1996:71-76.

32. Md-Zain BM: Molecular Systematics of the Genus Presbytis Columbia University; 2001

33. Md-Zain BM, Morales JC, Hassan MN, Jasmi A, Lakim M, Supriatna J, Melnick DJ: Is Presbytis a distinct monophyletic genus: Inferences from mitochondrial DNA sequences. Asian Primates J 2008, 1:26-36.

34. Vun VF, Mahani MC, Lakim M, Ampeng A, Md-Zain BM: Phylogenetic relationships of leaf monkeys (Presbytis; Colobinae) based on cytochrome b and 12S rRNA genes. Genet Mol Res 2011, 10:368-381.

35. Wich SA, Assink PR, Becher F, Sterck EHM: Playbacks of loud calls to wild Thomas langurs (Primates; Presbytis thomasi): the effect of familiarity. Behaviour 2002, 139.79-87.

36. Gurmaya K: Ecology and behavior of Presbytis thomasi in Northern Sumatra. Primates 1986, 27:151-172. 
37. Cracraft J: Species concepts and speciation analysis. Current Ornithol 1983, 1:159-187.

38. Cracraft J: Speciation and its ontology: the empirical consequences of alternative species concepts for understanding patterns and processes of differentiation. In Speciation and its Consequences. Edited by: Otte D, Endler JA. Sunderland: Sinauer Associates; 1989:28-59.

39. Eschscholtz F: Description of a new species of monkey (Presbytis mitrata). In A Voyage of Discovery in the South Sea, and to Behring's Straits: in Search of a North-east Passage, undertaken in the Years 1815, 16, 17, and 18, in the Ship Rurick. Edited by: Von Kotzebue O. London: printed for Sir Richard Phillips and Co; 1821:353-356

40. Kawamura S: Distribution and vocalisation of Presbytis melalophos and $P$. femoralis societies in Westcentral Sumatra - a summarised report. Kyoto Univ Overseas Res Rep Studies Asian Non-human Primates 1984, 3:37-44.

41. Megantara EN: Ecology, behavior and sociality of Presbytis femoralis in Eastcentral Sumatra. In Comparative Primatology Monographs, No. 2. Edited by: Ehara A, Kawamura S. Inuyama: Primate Research Insitute, Kyoto University; 1989:171-301.

42. Ey E, Fischer J: The" acoustic adaptation hypothesis" - a review of the evidence from birds, anurans and mammals. Bioacoustics 2009, 19:21-48.

43. Brandon-Jones D: Taxonomic affinities of the Mentawai islands surili Presbytis potenziani (Bonaparte, 1856) (Mammalia: Primates: Cercopithecidae). Raffles Bull Zool 1993, 41:331-357.

44. Meijaard E: Solving mammalian riddles: a reconstruction of the Tertiary and Quaternary distribution of mammals and their palaeoenvironments in island South-East Asia. PhD thesis The Australian National University Canberra; 2004.

45. Nijman V: Ecology and conservation of the Hose's langur group (Colobinae: Presbytis hosei, P. canicrus, P. sabana): a review. In Indonesian Primates. Edited by: Gursky S, Supriatna J. New York: Springer; 2010:269-284.

46. Wich SA, Assink PR, Becher F, Sterck EHM: Playbacks of loud calls to wild Thomas langurs (Primates; Presbytis thomasi): the effect of location Behaviour 2002, 139:65-78.

47. Meulman JJ, Heiser WJ: IBM SPSS Categories 19. 1989

48. Brockelman WY, Ali R: Methods of surveying and sampling forest primate populations. In Primate Conservation in the Tropical Rain Forest. Edited by: Marsh CW, Mittermeier RA. New York: Alan R Liss; 1987:23-62.

49. Felsenstein J: PHYLIP (Phylogeny Inference Package) version 3.69. Department of Genome Sciences, University of Washington, Seattle.

50. Peakall ROD, Smouse PE: GenAIEx 6: genetic analysis in Excel. Population genetic software for teaching and research. Mol Ecol Notes 2006, 6:288-295.

doi:10.1186/1471-2148-12-16

Cite this article as: Meyer et al: Acoustic structure of male loud-calls support molecular phylogeny of Sumatran and Javanese leaf monkeys (genus Presbytis). BMC Evolutionary Biology 2012 12:16.

\section{Submit your next manuscript to BioMed Central and take full advantage of:}

- Convenient online submission

- Thorough peer review

- No space constraints or color figure charges

- Immediate publication on acceptance

- Inclusion in PubMed, CAS, Scopus and Google Scholar

- Research which is freely available for redistribution

Submit your manuscript at www.biomedcentral.com/submit
C Biomed Central 